\title{
Penerapan Aplikasi Markerless Augment Reality untuk Pemodelan Mesin Injection
}

\author{
Alvino Octaviano ${ }^{1}$, Sofa Sofiana ${ }^{2}$ \\ 1,2Teknik Informatika, Universitas Pamulang Tangerang Selatan, 15413 \\ e-mail: 1alvinomail@gmail.com, ${ }^{2}$ sofiana82@gmail.com \\ Submitted Date: October $2^{\text {nd }}, 2019$ \\ Reviewed Date: October $4^{\text {th }}, 2019$ \\ Revised Date: October $5^{\text {th }}, 2019$ \\ Accepted Date: October 6 $6^{\text {th }}, 2019$
}

\begin{abstract}
The limited number of teaching aids is the general shortage of private schools due to the limited cost of procuring props for the PGM-FI sistem. The less interesting learning model is also a factor in the low value of students in certain subjects. Augmented Reality is a technology that develops in the world, combining two-dimensional or three-dimensional virtual objects into a real three-dimensional environment and then projecting these virtual objects in real time. in previous studies have introduced Augmented Reality Applications that still use markers. But the application still has limitations. The need for paper printing and sticking to the object to be studied. Through markerless technology other than without the need for paper printing and pasting. This application can further adjust the appearance of injection machines.
\end{abstract}

Keywords: Augmented Reality, PGM-FI, Android, Markerless

Abstrak

Terbatasnya jumlah alat bantu pengajaran adalah kekurangan umum sekolah swasta karena terbatasnya biaya pengadaan alat peraga untuk sistem PGM-FI. Model pembelajaran yang kurang menarik juga merupakan faktor rendahnya nilai siswa pada mata pelajaran tertentu. Augmented Reality adalah teknologi yang berkembang di dunia, menggabungkan objek virtual dua dimensi atau tiga dimensi menjadi lingkungan tiga dimensi nyata dan kemudian memproyeksikan objek virtual ini dalam waktu nyata. dalam penelitian sebelumnya telah memperkenalkan Aplikasi Augmented Reality yang masih menggunakan spidol. Namun aplikasi tersebut masih memiliki keterbatasan. Kebutuhan akan kertas cetak dan menempel pada objek yang akan dipelajari. Melalui teknologi tanpa penanda selain tanpa perlu mencetak dan menempelkan kertas. Aplikasi ini selanjutnya dapat menyesuaikan tampilan mesin injeksi.

Kata kunci: Augmented Reality, PGM-FI, Android, Markerless

\section{Pendahuluan}

Pendidikan sekolah menengah kejuruan semakin menunjukkan perkembangan yang pesat. Seiring dengan tingginyaperkembangan teknologi yang berbanding lurus dengan banyaknya kebutuhan bahan praktek yang dibutuhkan pendidik dan peserta didik. Dan mengajarkan berbagai macam teknologi, baik dengan cara mengandalkan power point ataupun melakukan dengan media online berupa e-learning. Sebagai seorang guru dituntut untuk selalu melakukan inovasi dalam menyelesaikan masalah transfer knowledge dan pengalaman kepada siswanya memberikan gambaran yang jelas akan konsep suatu teknik yang sulit dipahami ke dalam bentuk yang sederhana. Dalam implementasinya di lapangan dan di tempat siswa belajar jurusan Teknik Sepeda Motor (TSM) beberapa guru tentunya merasa pernah menemui kesulitan dalam hal ini.

Dari hasil pengamatan dan nilai yang didapat tentang sistem injeksi sepeda motor honda nilai siswa masih dibawah nilai kentuntasan belajar. Banyak faktor yang menyebabkan siswa mendapatkan nilai rendah dalam kompetensi memahami sistem bahan bakar bensin khususnya sistem injeksi sepeda motor honda. Salah satu faktor yang menyebabkan siswa sulit memahami materi injeksi adalah tidak tersedianya alat peraga sistem PGM-FI di sekolah SMK Fadilah. Kendati pada penelitian sebelumnya sudah mengenalkan aplikasi Augmented Reality yang masih 
menggunakan marker. Namun aplikasi tersebut masih memiliki keterbatasan. Perlunya pencetakan kertas dan penempelan pada objek yang akan dipelajari. Melalui teknologi markerless selain tanpa perlunya pencetakan kertas dan penempelan. Aplikasi ini bisa lebih menyesuaikan tampilan letak mesin-mesin injeksi Honda. Terbatasnya alat peraga tersebut merupakan kekurangan dari sekolah swasta pada umumnya karena terbatasnya biaya dalam pengadaan alat peraga sistem PGM-FI. Kurang menariknya model pembelajaran juga merupakan faktor rendahnya nilai siswa dalam mata pelajaran tertentu. Siswa akan semangat dan termotivasi jika dalam proses pembelajaran menarik dan menyenangkan.

Dalam mengatasi masalah tersebut dapat melakukan pendekatan teknologi yang memberkan visualisasi secara nyata. Sehingga pembelajaran dalam bidang pendidikan lebih menarik dan memakai teknologi terkini agar pelajar lebih meminati pembelajaran. Dengan ini solusi yang dibuat oleh penulis adalah pemanfaatan aplikasi Unity dan Vuforia dalam membuat aplikasi Markerless Augment Reality untuk pembelajaran Mesin Ijection di SMK Fadilah. Aplikasi ini dapat membuat sebuah atau beberapa objek sebagai marker untuk objek Augmented Reality yang akan dimunculkan. Dapat seperti Objek 2D, 3D, Animasi, Video, Suara dan lain-lain.

\section{Metode Penelitian}

Metode yang digunakan dalam membangun aplikasi ini menerapkan metode pengembangan sistem Rapid Application Development (RAD). Sistem ini mempunyai tiga fase, yaitu kebutuhan perencanaan, proses desain RAD dan fase implementasi. (Kendall, 2010)

\subsection{Pengembangan Aplikasi yang Cepat}

Metode yang diterapkan dalam membangun aplikasi ini dengan metode pengembangan Rapid Sistem Pengembangan Aplikasi (RAD). Sistem ini memiliki tiga fase, misalnya

kebutuhan perencanaan, (Kendall \& amp; Kendall, 2011).

\subsubsection{Tahap Perencanaan Perencanaan}

Pada fase ini, pengguna dan analis bertemu mengidentifikasi tujuan aplikasi atau sistem dan untuk mengidentifikasi persyaratan informasi dihasilkan dari tujuan-tujuan ini. Orientasi dalam fase ini adalah menyelesaikan masalah yang akan diselesaikan.

\subsubsection{Tahap Proses Desain RAD (Rapid Application Development)}

Fase ini adalah fase untuk membuat rancangan dan meningkatkan yang dapat digambarkan sebagai lokakarya. Penganalisa dan dan programmer dapat bekerja untuk membangun dan menunjukkan representasi visual desain dan pola kerja untuk pengguna.

\subsubsection{Tahap Implementasi}

Dalam fase implementasi ini, penganalisa bekerja dengan pengguna secara terjadwal selama lokakarya dan merancang aspek bisnis dan nonteknis perusahaan.

\section{Hasil yang Dicapai}

3.1 Rancangan UML

Dalam memodelkan proses yang terjadi pada rancangan Augmented reality menggunakan Vuforia akan dibuat ke dalam 3 bentuk model UML antara lain: Use Case Diagram, Activity Diagram dan SequenceDiagram.

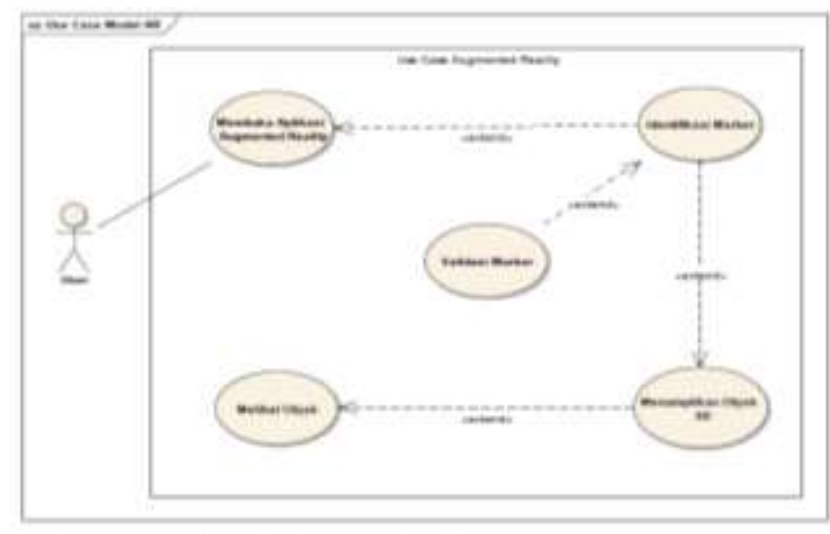

Gambar 1 Use case Buka Aplikasi Augmented Reality

Keterangan gambar

1. Use case: Buka Aplikasi Augmented Reality Actor: User Deskripsi: User membuka Aplikasi lalu sistem akan mengidentifikasi marker objek dan akan muncul objek sesuai marker.

2. Use case: Deteksi Marker

Actor: User Deskripsi: User membuka Aplikasi lalu sistem akan mengidentifikasi marker objek.

3. Use case: Tampilkan Objek 3D

Actor: User Deskripsi: User membuka Aplikasi lalu sistem akan mengidentifikasi marker objek, lalu sistem akan memvalidasi marker mana yang akan dipakai dan jika 
terdapat pada aplikasi akan muncul objek sesuai marker yang dituju.

\subsection{Rancangan Activity Diagram}

Rancangan activity diagram aplikasi Augmented Reality berdasarkan dari penjabaran masing-masing use case diagram diatas yang menunjukkan proses jalannya sistem aplikasi Augmented Reality secara detail dapat dijelaskan pada masing-masing gambar dibawah ini.

Activity Membuka Aplikasi Menggambarkan aktivitas ketika pengguna membuka menu. Pengguna langsung bisa mengkases kamera dan menjalankan aplikasi Augment Reality.

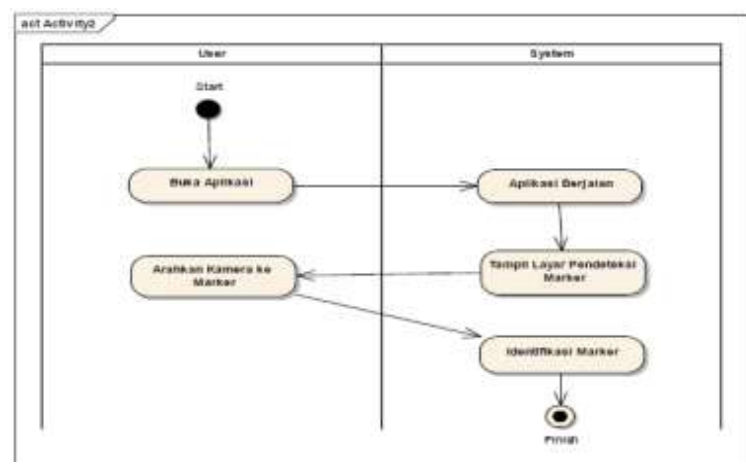

Gambar 2 Activity Membuka Aplikasi

\subsection{Activity Identifikasi marker}

Menggambarkan aktivitas yang terjadi pada aplikasi pengguna mengarahkan kamera pada marker yang ada pada letak yang dikehendaki. Dimana pada saat menjalankan aplikasi pengguna harus mengarahkan kamera pada bagian atau ruangan yang sesuai untuk mengetahui identitas marker.

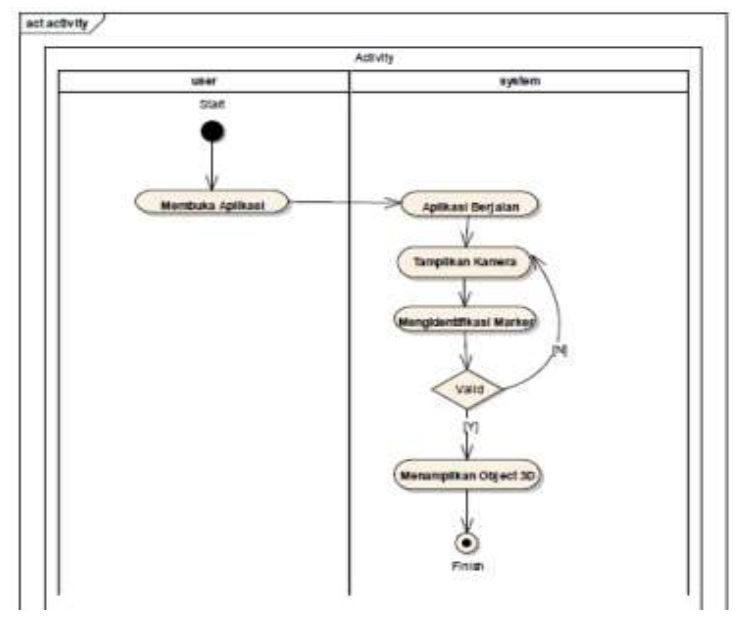

\subsection{Activity Menampilkan Objek Motor 3D} menggambarkan aktivitas yang terjadi pada aplikasi saat menampilkan objek mobil 3 dimensi. Dimana pada saat menjalankan aplikasi marker akan dideteksi dan aplikasi menampilkan objek 3 dimensi.

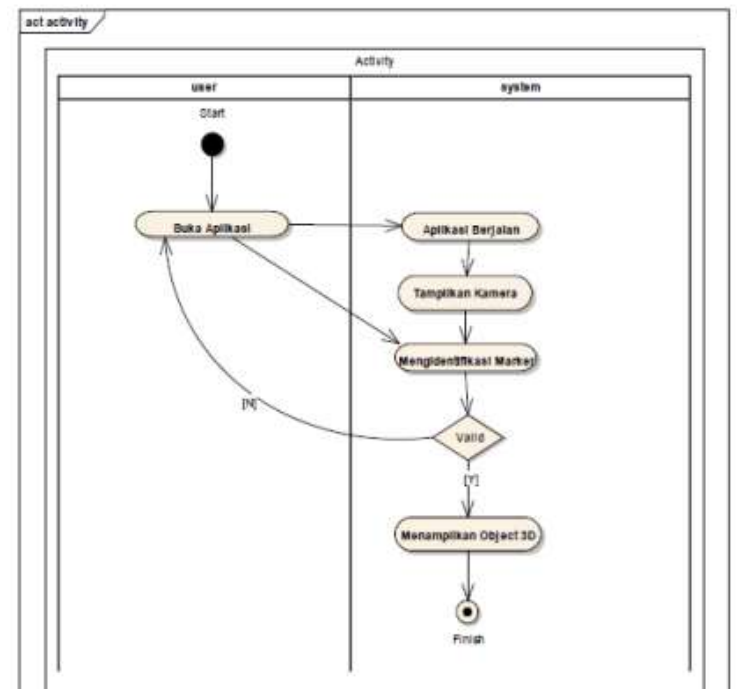

\section{Gambar 4 Activity Menampilkan Objek 3D}

\subsection{Rancangan Sequence Diagram}

Sequence diagram menggambarkan scenario atau rangkaian langkah-langkah yang dilakukan sebagai respon dari sebuah kejadian untuk menghasilkan output tertentu.

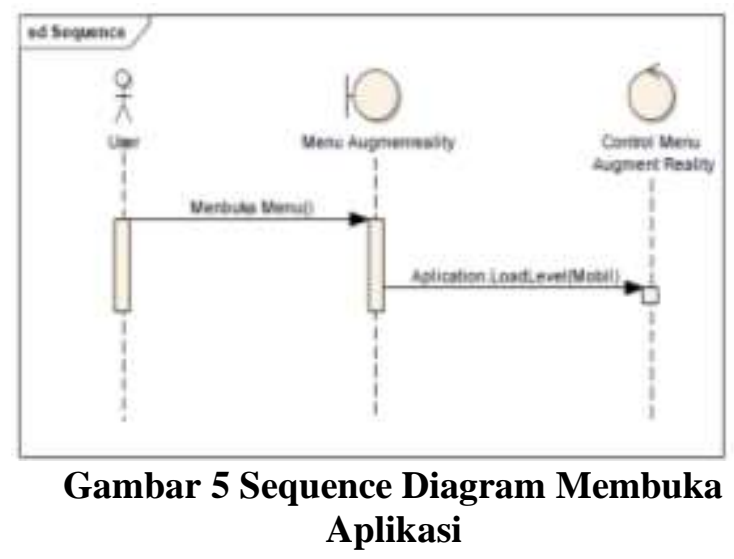

Dijelaskan bahwa user membuka menu Augmented Reality dan menggunakan method Application.LoadLevel aplikasi akan menampilkan halaman yang dipilih.

Gambar 3 Activity Identifikasi Marker 


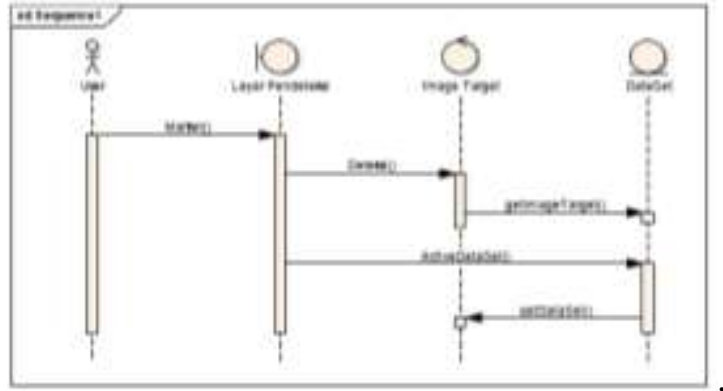

Gambar 6 Application.LoadLevel

\subsection{Sequence Diagram Identifikasi Marker}

Dijelaskan bahwa ketika mengarahkan kamera pada bagian mesin, kemudian sistem mengenalinya sebagi marker, lalu mencocokan data-data marker dengan data-data yang telah tersimpan di dalam DataSet. Setelah sistem mengenali data-data marker, kemudian sistem menampilkan 3D model dengan menggunakan method Load3DModel().

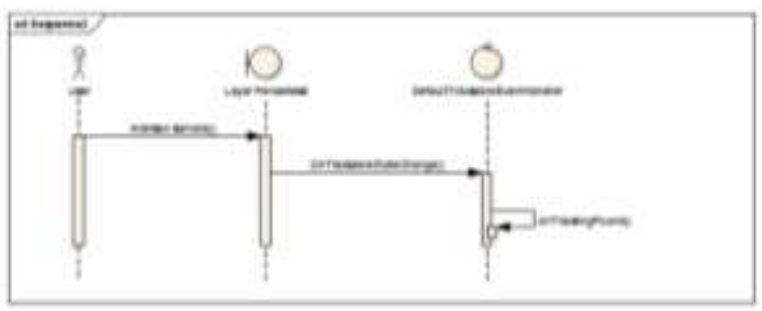

\section{Gambar 7 Sequence Diagram Tampil Objek}

Di jelaskan bahwa ketika mengarahkan kamer langsung kemesin, kemudian sistem mengidentifikasi marker dan setelah identitas marker diketahui maka sistem dengan method OnTrackableStateChanged akan menampilkan objek 3D sesuai dengan marker yang terbaca oleh kamera.

\subsection{Implementasi program 3 dimensi}

Mempersiapkan file-file pendukung, seperti image, icon, mp3, dan 3D object

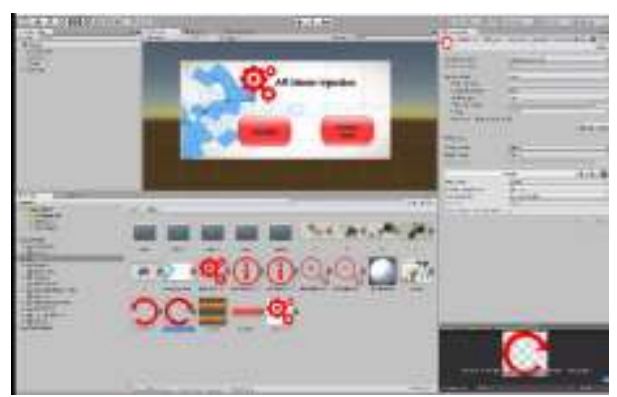

Gambar 8 File Pendukung

\subsection{Rangka Mesin}

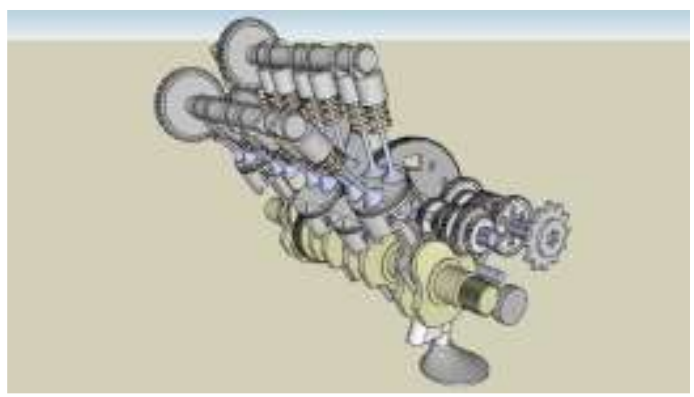

Gambar 9 Rangka Mesin 1

\subsection{Rangka Mesin 2}

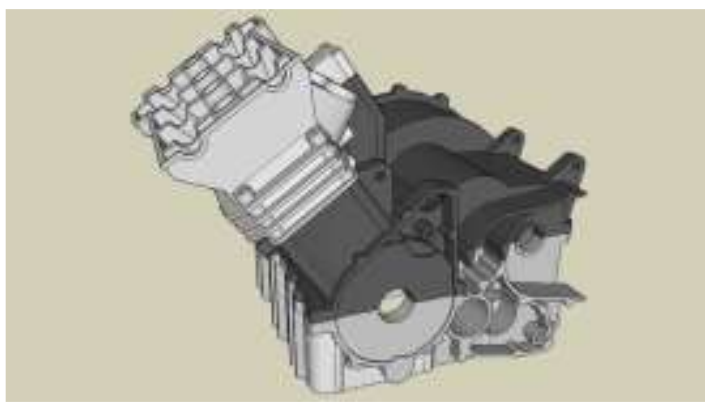

Gambar 10 Rangka Mesin 2

\subsection{Rangka Mesin 3}

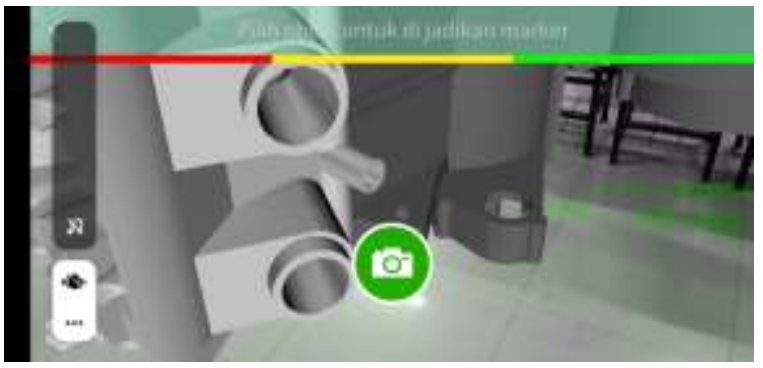

Gambar 11 Screen Markerless

4 User Interface

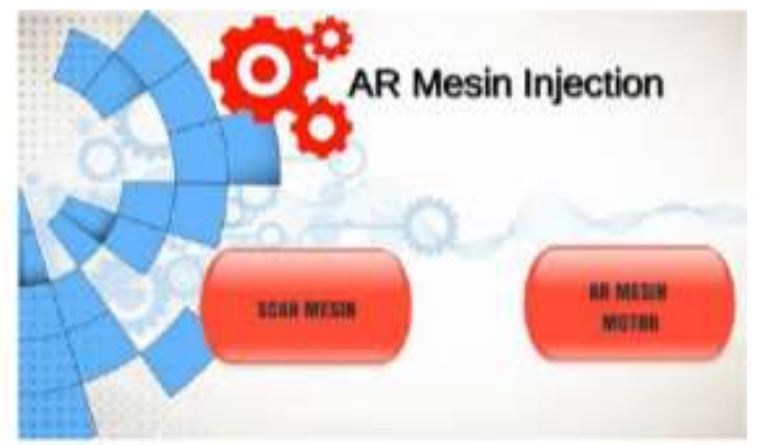

Gambar 12 User Interface 


\section{Kesimpulan}

Pada bahasan ini di buat rancangan interface dalam aplikasi yang terdapat di dalam smartphone. Proses kerja dari aplikasi ini dalam pembelajaran memanfaatkan teknologi smartphone android yang dimiliki masing-masing siswa. Smartphone nantinya akan instal sehingga dapat digunakan sebagai media belajar menggunakan Augmented Reality berbasis markerless.

Aplikasi tersebut terinstal selanjutnya smartphone tersebut akan menampilkan mesin sepeda motor tipe injeksi yang akan dipelajari oleh siswa. Ketika menekan tombol kamera maka akan mucul animasi / video berupa cara kerja sistem injeksi dan komponen-komponen injeksi pada layar smartphone masing-masing siwa. Video tersebut akan menampilkan cara kerja dari sensor bekerja kemudian mengirim sinyal ke ECM dan selanjutnya ECM memberikan sinyal ke bagian injektor untuk menyemprotkan bahan bakar. Tidak hanya cara kerja nantinya fungsi dari masing-masing sensor juga akan dimunculkan dalam media pembelajaran tersebut.

\section{Daftar Pustaka}

Kendall, K. E. (2010). Analisis dan Perancangan Sistem. Jakarta: PT. Indeks.

Sudjana, N. (2016). Penilaian Hasil Proses Belajar Mengajar. Bandung: PT Remaja Rosdakarya.

Usada, E. (2014). Rancang Bangun Modul Praktikum Teknik Digital Berbasis Mobile Augmented Reality (AR). Jurnal Infotel , Hlm. 83-88. 